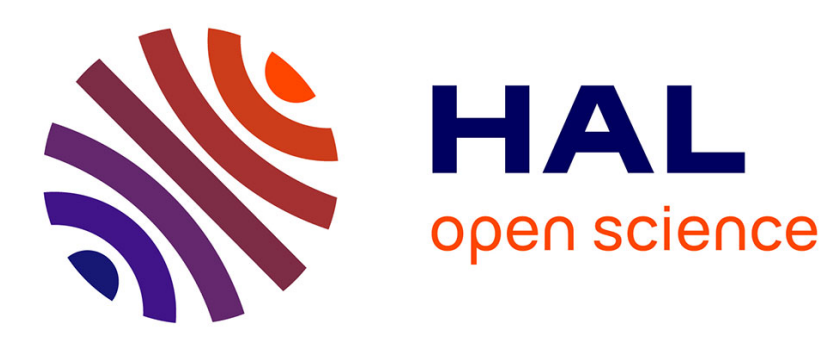

\title{
Poverty and Informal Economies
}

\author{
François Bonnet, Sudhir Alladi Venkatesh
}

\section{To cite this version:}

François Bonnet, Sudhir Alladi Venkatesh. Poverty and Informal Economies. David Brady; Linda M. Burton. Oxford Handbook of the Social Science of Poverty, Oxford University Press, pp.637-659, 2016, 9780199914050. halshs-01297260

\section{HAL Id: halshs-01297260 https://shs.hal.science/halshs-01297260}

Submitted on 3 Apr 2016

HAL is a multi-disciplinary open access archive for the deposit and dissemination of scientific research documents, whether they are published or not. The documents may come from teaching and research institutions in France or abroad, or from public or private research centers.
L'archive ouverte pluridisciplinaire HAL, est destinée au dépôt et à la diffusion de documents scientifiques de niveau recherche, publiés ou non, émanant des établissements d'enseignement et de recherche français ou étrangers, des laboratoires publics ou privés. 


\title{
Poverty and Informal Economies
}

Francois Bonnet and Sudhir Venkatesh

Bonnet F. and Sudhir Venkatesh. 2016. "Poverty and informal economies", in David Brady and Linda Burton (dir.), Oxford Handbook of the Social Science of Poverty, Oxford University Press, pp. 637-659

\begin{abstract}
Informal economic activity is a significant part of world production and distribution. This chapter reviews different core definitions (informal economic activities versus informal sector), different historical instances of "the" informal economy (in the Third World, under Communism and in contemporary Western cities), and different theoretical approaches (the dualist or development perspective, the legalist or neoliberal perspective, the structuralist or neomarxist perspective). We explore the different types mediation, dispute resolution and regulation that emerge out of informal economic transactions. We then focus more specifically on the informal economy in the everyday life of the poor, and argue that informal economic activities reward specific skills which are not valued on the formal labor market. We address methodological challenges to studying the informal economy in the conclusion.
\end{abstract}

\section{Introduction}

Informal economic activity is a significant part of world production and distribution. The most comprehensive recent study is by Elgin and Oztunali (2012), in which the shadow economy is estimated to be approximately $23 \%$ of world GDP. Informal economies occupies a central role in the lives of the poor. Low-income households depend on various forms of unregulated work in order to make ends meet. Criminal activities, such as drug trafficking, theft, or credit card fraud typically make headlines because of the risks involved and the deleterious impact on communities. For the urban poor, these activities can bring in significant resources into the home-and they carry significant social costs, but they do not constitute the bulk of underground revenue generation.

Criminal activities are only a small subset of the ways in which informal economies penetrate the lives of low income households. Much more common are socially legitimate activities, such as hair styling or gypsy cab driving, whose principal legal infraction arises because individuals fail to report their income to the State and other regulatory agencies. Among these socially legitimate activities, some lack certification and licenses while others depend on the infringement of regulation to be competitive (e.g., labor laws, sanitation codes). For all, their formalization could require not only a complete overhaul of the activity, but it may end up creating additional costs that might eclipse the benefits for individual participants. 
There are several phrases commonly used to describe informal economic activities, including black market, underground economy, and shadow economy. Their particular meaning varies by country of usage and by social context. ${ }^{1}$ There are some important distinctions in usage that we address below. In most definitions, constituent economic activity typically refers to unregulated income generation that are de jure illegal or that are legal but whose mode of operation does not fall under a formal regulatory body.

The purpose of this essay is to understand how the informal economy matters in the context of poverty and social inequality. We divide the presentation in three sections. The first section presents a brief history of the concept, as well as related theoretical perspectives and controversies. The second deals with the informal economic activities among the urban poor. And, finally, we conclude by reviewing methodological challenges and research priorities for the coming period of social science research on the urban poor.

\section{Defining Informal Economies}

\section{The informal economy between informal activities and the informal sector}

The concept of informal economic revenue generation appears under a variety of conceptual guises (Losby et al. 2002:1, Venkatesh 2008). Attention to such activities became popular in the social science literature after the Second World War as global national productivity seemed to be running alongside a second, parallel stream of commerce that was suggestive of the kind of traditional highly localized economies one found in pre-modern civilizations (Valentine 1978; Marable 1983; Fusfield and Bates 1984).

The first author to (explicitly) mention informal economic activities is Keith Hart (1973), a social anthropologist. During the 1960s, Hart conducted fieldwork among the Frafras, a group of poor Ghanaian migrants who moved about from rural districts to Accra (Ghana's capital) in search of material opportunities. Hart wrote, "Does the 'reserve army of urban unemployed and underemployed' really constitute a passive, exploited majority in cities like Accra, or do their informal economic activities possess some autonomous capacity for generating growth in the incomes of the urban (and rural) poor?" (Hart 1973:61).

Hart had identified practices rather than a coherent system of material interrelationships. Hart was studying income generation using the household as a unit of analysis. He described how poor people facing a context of low wages, inflation and lack of safety nets would engage in creative ways to make ends meet. At the same time the International Labor Organization (ILO) launched the World Employment Program, which spurred a set of studies in the Third World. The "Kenya Report" (ILO 1972) featured an entire chapter (pp. 223-232) on the "informal sector" (defined as tax evasion

\footnotetext{
${ }^{1}$ In the aftermath of the most recent European financial crisis, the self-employed Greek citizen who earns money, but who fails to pay his taxes, drew attention throughout the continent as an example of spreading informal economic entrepreneurship. The symbol of the Greek black marketer played a pivotal role in speeches by European officials who cited Greece's inability to support rational, modern, bureaucratic commerce.
} 
and lack of government regulation) which emphasized its innovativeness and dynamism.

Hart's research did not speak of the informal economy, but of "informal economic activities”, or "income opportunities.” By contrast, ILO's Kenya Report, focusing on firms (not households), aimed at describing an entire economic sector. Specifically, in the ILO's view, developing economies featured a "modern sector", which looked like a capitalist, rational, formal, modern, Western economy, and a "traditional sector", with small units of production, low productivity and little state regulation (Lautier 1994).

This initial distinction between practices and economic sector would open up a fertile analytic debate for decades. Viewed as activities, the informal sector becomes a hodge podge of activities that are only linked to one another by their common auspice as helping individuals to make sporadic revenue necessary for survival. Various social scientists pursued these adaptive mechanisms because they helped to counter a dominant discourse that portrayed the poor as lazy or unable to work (see Stack 1974, Valentine 1978). By contrast, those who viewed the unregulated practices as a distinct sector tended to focus on the formal properties of constituent markets: how big they were, what kinds of pricing and contracts defined them, and what models were needed to estimate their impact on any particular nation. While these two lines of thought are not necessary mutually exclusive, in practice, there have been two distinct streams of social science activity, in which the research has not engaged one another in any significant manner. One school of thought, rooted in the discipline of economics, has focused on measurement and national level impact. By contrast, another-at the intersection of sociology and anthropology-has sought to determine the practical consequence of such economies on the daily lives of those in low income households and communities.

Among those who see the informal economy as a distinct sector, there has been a tendency to simply rule out all activities that are by definition illegal. Thus, the influential work of Castell and Portes (1989) does not include a wide range of behavior, from drug trafficking to sex work, as falling within the "informal economy." Scholars distinguish licit from illicit exchange in order to separate "informal" from "criminal" pursuits (Centano and Portes 2006). That is, Portes and Castells (1989) differentiate criminal economies from clandestine exchange that would otherwise be legitimate if licenses were obtained and revenue was reported to government bodies. For those who adopt this perspective, "crime" constitutes a more serious moral as well as a legal violation, and so must be kept distinct. Most literature reviews (Losby et al. 2002; Chen et al. 2002; Gërxhani 2004) exclude criminal activities from a meaningful definition of the informal economy.

Such differentiation of economic pursuits by the legitimacy of the good or service being exchanged ultimately has limited analytic purchase. We would hold that a priori definitional distinctions between licit and illicit is only marginally helpful when trying to understand social inequality and poverty-we will return to this issue in our concluding discussion of methodology. In fact, such a framework falls under sharp criticism by the in situ concrete overlap among legitimate and various illegitimate practices that characterize the daily lives of low income households (Valentine 1978; Edin and Lein 1997; Venkatesh 2006). In practice, studies show that for poor people, a variety of resources come into the home-monetary, barter, shared property and assets, etc. These 
goods and services cannot be neatly differentiated by their licit or illicit provenance.

Thus, as a foundation for sociological analysis, making such distinctions will be only minimally helpful. Rather than differentiating one practice from another on the basis of moral criteria, it may be more fruitful to consider the ways that informal economies (including criminal enterprises) participate in the full economic profile of a society and the overall social reproduction of the poor. Other scholars have adopted the view that the entire range of un-regulated work should be considered without $a$ priori analytic bias; this view has tended to support an examination of the impact of informal work on households and individuals (Gaughan and Ferman 1987).

\section{Three types of informal economies and their corresponding problems}

Within the diversity of informal activities, we distinguish three types, each of which corresponds to a distinct different scientific problems. The first is the informal economy in the Third World, to which corresponds a problem of development. The second is the "second economy" in the Soviet Union, which complicates the question of the relationship between formal and informal. The third is the informal economy in contemporary Western societies.

The informal economy has first been studied in the Third World (ILO 1972; Hart 1973) in the context of development studies. Early economic theories of development, based on Rostow's stages of growth model, conceptualize development as a sequence of stages, from traditional rural economy to advanced post-industrial societies of mass consumption. An entire field of study has been devoted to the fate of rural migrants to rapidly developing cities who are less pulled by the development of industry than pushed by misery, desertification, mechanization of agriculture, unfair competition from mechanized and subsidized western agriculture and the consequences of structural adjustment programs. Many of these urban dwellers live in informal settlements (slums) and live off informal activities. Debates mostly concern the question of whether the informal economy is an obstacle or an opportunity for development.

A second context of scholarly study of the informal economy is the "second economy" in Soviet Union, before the fall of communism in Eastern Europe. Grossman (1977:25) defined the second economy as the set of activities that were for private gain and/or that were against the law. This definition included theft of state property, corruption, and crime, but also-and more interesting to Grossman-economic exchange where "demand-and-supply relations reign almost supreme". Some of these transactions were tolerated if they remained discreet, some were actively prosecuted, and some "economic crime" was met with the firing squad (Grossman 1977). Doctors, teachers, and tailors moonlighted for private gain; construction, home repair and rented apartment was most likely done in "semi-legal" ways (Katsenelinboigen 1977; 1990); creative ways of stealing the company were found to supplement the income of indispensable employees, such as good chauffeurs; and illegal flea markets made available goods that were impossible to find otherwise (Grossman 1977; Katsenelinboigen 1990). For instance, a kiosk woman in Romania was renting her one copy of Newsweek by the hour (Sampson 1987:136). As Grossman (1977: 29) argues: 
"The enormous variety and occasional complexity of illegal and semi-legal activities... appear to be limited only by human ingenuity, though, naturally, the most ingenious schemes, being presumably also the more successful ones, tend to escape identification by Soviet authorities and detached observer alike." Instead of being a residue of presocialist mentality, the "second economy" was thriving. What made the second economy so fascinating to Russian émigrés and American economists was that it worked under the supply-and-demand market assumptions of modern capitalism, disproving the viability of a centrally planned economy not only because it addressed its shortcomings, but also because it was an "island of capitalism" in nature (Sampson 1987). Grossman (1977:40) and Stark (1989:657) analyzed the second economy as (respectively) a "spontaneous surrogate economic reform" and a "force of marketization".

A third line of research on informal economies focuses on advanced postindustrial societies. Here, the efforts can be subdivided in several categories. On the one hand, Sassen and others have focused on informalization in global cities (see discussion of structuralist perspectives below). They do not necessarily equate informalization with the urban poor, but they are careful to note that such economic spheres have very unstable work arrangements and can be exploitative. A second line of inquiry has focused specifically on the urban poor (Stack 1974, Valentine 1978, Fusfield and Bates 1984, Venkatesh 2006, Duneier1999). This research has continued apace since the 1960s when scholars realized that pockets of poverty persisted midst post-war affluence. In this tradition, the growth of an informal sector is linked to the demise of Fordist models of employment (job security, strong unions) and the persistence of concentrated poverty that requires individuals to look for alternate means of social reproduction. Informality is a means of survival among disenfranchised populations but also a factor reproducing their alienation from the social mainstream. As such, scholars view informal economies as both cause and consequence of inequality. A final area of inquiry focuses primarily on macro-economic effects of informal economic activity. Here, the principal concern has been to understand how much revenue and manpower is not accounted for in standard economic models - and, in turn, what tax loss is being incurred by governments. There is only tangential concern in such studies for the fate of low income populations.

\section{Theoretical perspectives and controversies}

The typology of Chen, Jhabvala and Lund (2002:6) offers a useful starting point for a discussion of the relationship of informality and inequality. The authors outline a threepart categorization of informal economic activity, based on the premise that the informal economy and mainstream economy must be thought of in relationship to one another. This relationship is either dualist, legalist and structuralist depending on the relationship of illegitimate and legitimate modes of exchange.

(1) The dualist (or development) perspective on informal economies builds on the central theoretical contributions of dual labor market theory (Doeringer and Piore 1971). This perspective adheres to a conventional labor market classification. Namely, the primary sector includes well-paying legitimate jobs, a secondary sector is based in unskilled, temporary employment, and finally the informal sector and the illegal criminal 
sector make up the remainder (see also Losby et al. 2002). In the dualist perspective, the informal economy is thought to function more or less independently of the legitimate sector. There is relatively little interest among proponents of this view for overlaps and permeable boundaries.

This perspective tends to conflate informal economic activity with the survival practices of low-income populations-as opposed to, say, white collar underground revenue generation, organized crime, or gambling across income strata. The poor are presumed to work irregularly, if at all, in legitimate jobs, and so the informal economy becomes their principal space for earning revenue for basic survival (Marcelli, Pastor and Joassart 1999). The notion is that the informal economy is a safety net for the poor (see also Ferman, Henry and Hoyman 1987; Stack 1974).

Not surprisingly, perhaps, dualist perspectives draw a sharp contrast between the informal economy of developing countries, where basic survival is a concern for a much larger sub-population, and advanced industrialized countries, where the externalities of market vicissitudes occasionally drive people into the underground sector. For instance (and according to estimations), the informal economy represents $12 \%$ of the GDP of OECD countries, $25 \%$ of the former Soviet Union's, and $44 \%$ of Africa's (Gerxhani 2004:268).

A drawback of this perspective is that it ignores many of the ways in which lowincome populations are central to both formal and informal economies. Low-income populations are critical both in terms of provision of labor in the mainstream economy and as consumers. Despite the recognition of the use of unregulated work for survival, the dualist perspective can lead to arbitrary and rigid classifications that isolate the poor into a distinct economic realm.

In addition, informality is a legal construct, not an indicator of vulnerability. There are many ways in which non-mainstream activities can be undertaken by individuals who are not in materially disadvantageous positions. And some such activities may be quite rewarding despite the risks involved. Examples include successful street vendors and food-carts, off-the-book plumbing and home maintenance service, and high-end sex work. ${ }^{2}$

(2) The legalist (or neoliberal) perspective originates in the work of Hernando De Soto (1989). Unlike the dualist perspective, the legalist view places heavy emphasis on the role of the state, particularly in terms of state regulations that support the creation and maintenance of economic activity. Indeed, in this view, some scholars have gone so far as to write, "the relationship of the informal economy and the state is, by definition, one of inevitable conflict" (Centano and Portes 2006: 30).

De Soto himself argued that informal economies were neither a function of poverty nor a structural necessity of late capitalism. Instead, he suggested that

\footnotetext{
2 The small size of economic units—often an item in defining informality-is also not relevant: many professionals (doctors, lawyers) and most shopkeepers are self employed or have a small staff. Even the criteria of avoiding state regulation is weak. Most formal firms routinely disregard regulations and laws: banks launder money, industries pollute, arms dealer smuggle weapons; non-profits, political parties and bureaucracies organize clientelism and corruption. In particular, systematic tax evasion by the richest and most established individuals and firms is widespread: about $8 \%$ of the global financial wealth of households is held in tax havens (Zucman 2013).
} 
informality is a choice made by rational actors facing a legal environment that hinders creative entrepreneurship. Thus, if the state is not seen as welcoming particular forms of material gain, those so interested will move underground to pursue their interests.

De Soto focused specifically on the Peruvian context. He argued that the country's poor would forgo developing their ventures in an un-regulated realm if they believed that the state could operate in a non-corrupt fashion. Instead, low income persons found government bureaucracies with little interest in supporting their needs. To model their argument, De Soto and his team of researchers conducted an experiment. They established a small clothing factory as a means of gauging the challenges of working with the Peruvian State bureaucracy. Using bribes only when absolutely necessary, it took 289 man-days to complete the task, which De Soto found to be an unnecessarily long time. In this manner, De Soto argued that the informal economic activities of the poor were the behavior of market actors rationally responding to economic incentives.

The legalist perspective holds that low income populations can be understood as more than simply survivalists - which is the dominant characterization of the dualist view. Instead, the poor are innovators and rational actors who are realizing aspirations that would be recognizable to anyone in that society. What the poor lack however-and what distinguishes them from other classes-is support from the state for their property rights and enforcement of the contracts that they develop in their petty accumulation strategies. Without this backing, the poor are assigned to work in economic sectors that are inherently stable and on the societal margins.

Adherents to this legalist perspective also argue that the informal economy should not necessarily be viewed as a social problem. Instead of being policed and eradicated, it should be supported and formalized (see Gerxhani 2004:286-292 for a discussion). And, conversely, limiting the deleterious consequences of excessive state regulation would help reduce the number of low income households who end up turning away from the mainstream for their material pursuits. In other words, in the legalist perspective, advancing the interests of low income populations is best pursued by formalizing their inclusion into the economy via state-based supports.

Formalization includes giving economic actors on the fringes access to modern legal institutions of capitalism such as credit, legitimate property rights, bankruptcy laws, commercial laws, and the power of enforceable contracts-all of which can support regulated accumulation. ${ }^{3}$

A criticism of the legalist perspective is the failure to discuss how the basic organization of capitalism creates the conditions for some families to rely on informal work, where violence and extortion are ever present, and where women and children are particularly likely to suffer exploitation (Davis 2006: 179). Competition among the poor makes income minimal, which explains why many people turn to "gambling, pyramid schemes, lotteries, and other quasi-magical forms of wealth appropriation" (Davis 2006:183).

\footnotetext{
${ }^{3}$ Another characteristic of De Soto's work is the way the state is perceived. In the development literature, the state is unable to control its territory, hence the informal economy: it is because the state cannot field enough civil servants, or cannot pay them adequately, that corruption, clientelism and lack of manpower give way to the rise of informal activities. De Soto argues instead that the informal economy exists because the state is too controlling, hence the need for deregulation, or, more precisely, to formalize informality by undoing regulations.
} 
In addition, simply legitimating the commerce of low income populations by granting property rights and official titles may not be feasible as a policy approach to inequality (Gilbert 2002). While the formalization of informal activities is a key medium to enable poor people to trade their assets-as proponents of the legalist perspective contend, it is not the case that all economic actors who work informally to accumulate capital and enter into mainstream markets. Many may prefer the capacity for flexible work, on a temporary basis, that can enable them to bring resources into the home as needed. The rigidity of wage labor that is recorded on the books, and the expense of contracts, may end up increasing their vulnerability.

(3) The structuralist (or neomarxist) perspective, championed by Castells and Portes (1989; Portes and Sassen-Koob 1997) deviates from both dualist and legalist perspectives. The informal economy in advanced countries enables capitalists to reproduce "uncontrolled, exploitative relationships of production" by doing away with labor unions, and labor, health and environmental regulations. Capitalists are thus able to cut costs and increase their competitiveness (Portes and Walton 1981), "under the auspices of government tolerance" (Castells and Portes 1989:27). Workers-especially, but not only, undocumented migrants-experience "downgraded labor" (Sassen-Koob 1984). In this perspective, informalization is a logical development of the shifting needs of capitalism. The need to reduce the production costs of commodities motivates industrialists to use informality as a cost saving principle (Sassen 1994; 1997).

The structuralist perspective has been particularly attractive for scholars observing so-called "global cities" in which the fast pace of economic change results in off-the-books activity that is virtually impossible to regulate through conventional means. Informality enables newcomers, such as immigrants and undocumented workers, to quickly establish a foothold via their inclusion into mainstream economic circuits-albeit in a way that can be exploitative.

Structuralists criticize dualist perspectives by equating the informal economy with poverty. As Castells and Portes write, "We depart from the notions of economic dualism and social marginality which have been so pervasive in the development literature" (1989:12). Portes and Sassen-Koob (1997) make a distinction between informal entrepreneurs and informal workers, the former being more likely to benefit from informality (no taxes, no regulations, no unions) and the latter being more likely to be exploited. The distinction between entrepreneur and workers is a notable attempt at defining the informal economy because it underlines how the label "informal economy" mixes up vastly different situations. ${ }^{4}$

\footnotetext{
${ }^{4}$ It is worth mentioning the work of David Stark (1989), who makes an important contribution in this regard by challenging modernization theories-both capitalist and Marxist-that perceive informal and second economies as relics of a pre-industrial or pre-socialist past. By contrast, Stark (1989: 639) argues is that "Informalization is a product of the modern and the bureaucratic." The informal economy is a consequence of "regulatory bureaucratization", and the second economy is an "alternative institution in which skills and effort find a higher rate of returns." In other words, the informal economy can also be constituted by the active agency of individuals who exercise preferences in relationship to a wide field of economic opportunities-legitimate and informal. The informal economy in any society would hence help the analyst to understand not only the scope conditions of the wider economy-who it serves, what kind of commerce it can support, etc.-but
} 
The idea of the informal economy as fundamentally exploitative and being functional to the needs of late capitalism contrasts with the notion that informality may be understood as a "popular economy", or a "counter-economy". In this latter view, the formal sector is the locus of capitalism, rational calculation and contractual relations, while the informal economy gives rise to solidarity, deepened and enhanced social bonds, in particular at the local and familial level (Lautier 1994). In England for instance, research with 511 respondents from poor and rich neighborhoods has that rich and the poor equally use off-the-books labor. However, the rich favor market-like economic relations, and they quit using informal arrangements once their needs have been met. Such instrumentalism is not present among the lower income populations, for whom informal arrangements are means to strengthen social relations among friends and relatives (Williams and Windebank 2001).

The American version of this can be traced back to the post-1960s societal concern with the social exclusion of the native black population. The state of black America led to concerns that an alternate form of capitalism-criminal, immoral, primitive-was holding back social progress in low-income ghettos. A dominant view was that an "underground economy" saturated black urban communities such that mainstream economic progress was being hampered. Against this perspective, various scholars argued that black Americans were more than capable of sustaining legitimate, mainstream forms of accumulation (Cross 1969, Fusfeld and Bates 1984, Gaughan and Ferman 1987). Some anthropologists suggested that the material foundations of black ghettos as a whole should be thought of via the dualist perspective: as different, not necessarily as deficient (Hannerz 1969; Stack 1974).

In subsequent periods, studies of the underground economy in the US became primarily opportunities to publicize the hardships among the low-income populations. The proliferation of studies of the urban underclass (see essays in Jencks and Peterson 1991) pointed to debilitating effect of organized criminal activities for low-income neighborhoods in general, and for urban youth in particular. One strand of research focused on the consequences of informalization on youth who, in their adolescent years, began drifting away from mainstream work toward illegal enterprises. As youth dropped out of school and entered into illicit economies, it became more difficult for them to re-establish their pathways in socially legitimate economies at a later date (Bourgois 1996). Other work has examined the effects on adult populations (Anderson 1990, Duneier 1994) by looking at the ways in which informal economies prevent black and Latino men and women from accumulating the social and economic capital necessary to create long-term stability for themselves and their families. The writings on global cities (Abu Lughod 1999; Sassen 2001) extended this argument by noting the ways that immigrants in urban centers became drawn into informal labor markets (and simultaneously excluded from the high growth sectors of the urban economy).

Thus, in these early considerations, the focus was on the articulation of economic and political systems. Scholars were interested in the role that the underground economy played in generating inequities, but they were not necessarily concerned (as they are today) with strategies to re-integrate earners and workers who toiled on the

also the ways in which individual entrepreneurs might move to un-regulated domains to pursue their economic interests. 
margin. Instead, the underground economy was interpreted in political-economic terms via a contentious relationship to the broader capitalist economy. It was seen by some as a potential space through which people could create more humanistic forms of economic exchange. For others, it might be the hotbed of socially revolutionary activity (see Lautier 1994).

\section{What types of regulation do emerge out of informality?}

At its core, an informal economic action is an exchange of a good or service between (at least) two parties that occurs via some form of non-state based regulation. The simplicity of this transaction belies a complex social structure that enables multiple exchanges to occur on a daily basis and, for the most part, in smooth fashion. In the formal economy, the institutional apparatus of conflict resolution is ultimately backed by the state's capacity for coercive violence. However, unlike the mainstream economy, in which a battery of institutions-from courts and licensing agencies to exchanges and tax authorities-regulate and provide stability to the parties by disseminating information on prices, by specifying resources for disputes, the underground economy typically has no such identifiable structure that can house buyers and sellers. In the informal economy, no such institutional apparatus exists. Instead, a variety of other venues, from community courts to third-party brokers (Lewicki et. al., 1992), might exist to help individuals address conflicts and ensure that justice is meted out (Merry 1990, 1993; Venkatesh 2007, 2013, Bourgois 1996). Attentiveness to the ways that such mediation and dispute resolution occurs can also shed light on the ways that informal economies reproduce conditions of inequality in a given society.

To begin, the absence of the state leads to three types of problems that arise in the context of informal economies. The most common disagreements occur over pricing and contracts. Buyer and seller each recall a different promise of payment or pricing structure, two traders might argue over a revenue split, and so on. A second source of dispute occurs over property rights: two individuals might argue over the right to occupy a public space, such as a park or a street corner, or they might haggle over intrusions that result from competitive bidding and marketing of services to potential clients. A third conflict can arise over the appropriate form of mediation and punishment for a given infraction.

Such problems are not inherently destabilizing. However, for the poor, their occurrence can be detrimental for two reasons. First, the ubiquity of underground markets means that such problems are prevalent and demand a significant amount of the energy of low-income households. As the poor spend more time and resources managing highly localized economies that provide resources and opportunities, there is little left for more productive purposes. As a consequence, informal economies by nature are almost always localized, idiosyncratic and difficult to integrate into the wider society at any scale (Rauch and Evans 2000). Second, the repeated use of non-state based means of resolving conflicts can pose serious threats to the ability of poor households to function in the wider society. That is, paradoxically, the more that poor populations are able to show innovativeness and ingenuity with respect to their investments and engagement in the informal economy, the easier it is for the dominant society to view 
them as unfit to participate in the legitimate sphere.(Castells and Laserna 1989). A common problem in the US arises because the poor end up failing to support the law enforcement institutions of the State-preferring instead to rely on their own dispute mediators. This becomes one factor among others that exacerbates the crisis of legitimacy of police in poor communities (Meares 2002, 2008).

Within low-income environments, the forms of regulatory response that one finds to such conditions are twofold. On the one hand, a vibrant redistributive justice movement over the past two decades has created para-state mechanisms of redress in which the state participates alongside other institutions, but agrees to share authority over mediation and punishment (Muncie 2007). These include local community policing initiatives that are common in the US as well as community courts that offer reduced sentences for individuals who are willing to work with community-based organizations to reduce the likelihood of future involvement in criminal activities (Merry 1990). There are also many highly localized cases in which non-State based methods of redress help local citizens to cope with the disputes that arise over informal economic activities (Venkatesh and Kasimir 2007, McRoberts 2005).

It should be noted that the forms of community-based redress, whether involving the State or not, do not necessarily signal an entirely different culture or way of life. For example, some regulatory movements are modeled after (neoclassical) market economic structures. De Soto argues that informal entrepreneurs operating outside the purview of legal regulations "spontaneously" create rules derived from the logic of the market economy (De Soto 1989:xviii). Similarly, Katsenelinboigen (1990) inferred from his study of the second economy in the USSR that a market economy derived from human nature ("human psychology has not changed", "people have natural vices"). In fact, the little we know about informal regulations of informal activities suggests that conflict resolution is grounded in interpersonal ties (Venkatesh 2006). Trading parties must rely on implicit norms or a priori codes that specify fair conduct, expected valuation, acceptable currency, and methods of redress for grievances. For instance, in the case of the second economy in the former Soviet Union, personal ties were central to the functioning of the second economy. Corruption was widespread, but one had to know who to bribe; corruption often involved bringing gifts, which personalized relations (Grossman 1977). Sampson (1987) stresses the importance of primary ties, of friendship to reduce risks of being reported to the authorities; he notes that underground factories were often run by Jews who relied on ethnic solidarity to avoid legal troubles. How these social functions of exchange are carried out can tell us quite a bit about the overall lives of the poor.

\section{The informal economy in the everyday life of the poor}

Underground exchange in poor neighborhoods shapes not just the lives of buyers and sellers of goods and services, but the wider population who come into contact with those engaged in unreported trading. The inclusion of underground economies in scholarly work becomes a means for scholars to raise a host of concerns about life in poverty.

Informal economies appear consistently in studies of law enforcement and policing. Urban policing strategy is overwhelmingly shaped by the behavior of those involved in illegal economic pursuits (Skogan 2003, 2006; Fung 2006; Moskos 2008; 
Venkatesh 2008; Jackall 2009). However, these studies typically do not offer a substantive analysis of the economic activities per se, other than to note their existence and significance for the dynamics of local policing. Similarly, illicit exchange can be a means to talk about the wider social organization of urban poor communities. Several studies have suggested that the presence of informal economies can create social divisions that pit various households against one another. Elijah Anderson's work (1999) differentiates families in urban poor social contexts via two different value orientations. In their efforts to live according to mainstream values, "decent" families are waged in a battle with those adopting a "street" orientation; the latter are those whose lives are centrally embedded in informal economies. Decent families worry about children who are playing with their "street" counterparts; they must navigate public spaces where underground entrepreneurs congregate; they suffer the continuous presence of law enforcement and an atmosphere of criminality. Venkatesh (2007) and Meares and Kahan (1998) also adopt a neighborhood-level focus; however, their respective studies focus on those who, via outreach, community organizing, mediation, or protest, engage the sellers of informal economic goods in an effort to restore public safety. They do not make value judgments that differentiate "decent" from "street" households, and instead, they examine the ways that informal economic activity creates social problems that require a collective response.

A number of scholars have examined the impact of underground exchange and criminal opportunity on individuals (Khoury 1995; Fitzpatrick 1997; Vega and Gil 1999; Wilson 1999). Alford Young's ethnographic study of marginalized black men (2004) suggests that individual perceptions of mobility and decisions to pursue economic paths are framed with an understanding of the potential sources of illegal revenue generation in existence. Philippe Bourgois' research on young men in Spanish Harlem similarly examines the role that underground economies play in motivating young men to choose socially legitimate work pathways (Bourgois 1996). Although Bourgois' study is based in a group of crack-cocaine dealers, the two authors are similar in pointing to the ways that informal exchange serves as an ever-present specter that haunts every young man and woman in urban poor neighborhoods. Even if they never participate directly, they make their decisions with an awareness that such opportunities exist and are being chosen by peers and acquaintances. The work of Kathryn Edin and Laura Lein has examined the interplay of individual and household contexts in assessing the role that informal economies play in the lives of the urban poor (Edin and Lein 1997). In such studies, it becomes clear that individual decisions to pursue opportunities for illegitimate gain are framed by the pressures that stem from the needs of the overall household.

\section{Informal activities reward specific skills}

Drawing on Wilson and Portes (1980) and Portes and Bach (1980), Thery (2014) conceptualizes informal activities as an economic space where specific skills get rewarded-skills that are not rewarded by the formal economy. For instance, the moral and physical ability to exert extreme violence is not rewarded on the formal labor market, but it is valuable to criminal endeavors (Bourgois 1996, Contreras 2012). "Street smarts" is another example of skills that are useful to informal endeavors but inadequate to most high-productivity service jobs who are available in contemporary 
global cities.

For instance, not all women are willing to sell sex, but those who do may earn more than what their marginal productivity in the legitimate economy would have them earn. Weitzer $(2005,2009)$ 's reviews suggest that most of the literature on sex workers is about work conditions, as opposed to economic activities. Little is known about pricing, about how much sex workers really earn, what do they do with the earnings, and what kind of professional career develop after sex work (for an exception, see Rosen and Venkatesh 2008). The literature about customers, who is less developed, focuses on their motivations to patronize sex workers, and to which extent they abuse them (Monto 2000, Kern 2000, Macleod et al. 2008); and little is known about third parties, such as pimps (see nonetheless Decker, 1979: 238-258; Hoigard and Finstad, 1992; O'Connell Davidson, 1998; Chapkis, 2000; all references found in Weitzer 2005:227). Another aspect of third-party involvement that might be studied under the heading of the informal economy is sex trafficking. But sex trafficking studies are less interested in the economics of traffic and more in the critique of human/women's right abuse (Farley et al. 2003), or in the deconstruction of the critique (Bernstein 2012). Sex work exemplifies how what is defined as criminal by a given state varies in time and space. Consider the example of sex work. Both the act of buying sex and selling sex are illegal in most of the United States, Africa, the Arab world, and in most of Asia, with extreme variations in enforcement. In Canada, Argentina, Brazil, and most of Western Europe, only the pimping is illegal. In Germany, the Netherlands, Turkey, and many Latin-American countries, sex work is legal and regulated; in Sweden and Norway, selling sex is not illegal per se, but buying sex is. The economy of sex work is shaped by the legal context: the sector may be entirely informalized by way of its criminalization, or may give rise to a two-tier market in countries that authorize sex work, with a formal sector regulated by the state, and an informal sector. Prostitution, but also drug trafficking and gambling are quintessentially economic activities that happen to be often illegal and therefore operate outside the state's regulation.

The study of gambling - another activity that is transactional in nature and arbitrarily informalized by way of state regulation-also illustrates how the literature tends to overlook its "informal economy." One way to not study gamblers as actors involved in informal economic transaction is to study the more pathological aspects of gambling, such as related alcohol abuse (Welte et al. 2001), psychological disorders (Petry 2005), the impact of new technologies and their enhancing effect of the gambling experience (Schull 2005), or the relationship between casino gambling and street crime (Miller and Schwartz 1998). A variation on the focus on the pathological aspects of gambling is to organize the literature as a debate between functional analyses of gambling and anomie/alienation perspectives (Frey 1984). The sociology of gambling departs from the pathologizing perspective to focus on the different subjective experiences and the different subcultures of gambling (Neal 1998; Aasved 2003), the "seductions of gambling" and the thrill associated to it (Cosgrave 2006). What gets closer to an "informal economy" perspective is the body of work that examines legalization and the state regulation of gambling (Eadington 1976; Cosgrave and Klassen 2001; Cosgrave 2006). An example of a study of the informal economy of gambling can be found in Light (1977). Light studies numbers gambling among the African American urban poor-a community notoriously deprived of financial services. Light describes how numbers 
gambling work alongside usury to provide access to credit to community residents.

A prominent empirical vehicle to study the underground economy is via the practices of street gangs and the drug economies they control. Illicit drugs are an undoubtedly significant component of the informal economy (on the economics of drug trade, see Caulkins and Reuter 1998; Reuter 2003; Reuter and Caulkins 2004; Leeson 2007), and gangs are sometimes part of this economy. Fagan (1996) argues that American gangs became more involved with the drug trade with the crack cocaine epidemics. Dominant theoretical perspectives in the study of gangs in sociology emphasize social disorganization perspectives (which emphasize explanations in terms of poverty, victimization, non-nuclear family structures, and so on) and control theories (which argue that criminals, at heart, act impulsively) (Wood and Alleyne 2010:103). Psychological explanations of the gang phenomenon stress that gang members are more likely to exhibit psychopathic tendencies and low IQ (Wood and Alleyne 2010:106). Research in these perspectives tends to not see gangs as (informal) economic actors. Bourgois (1996)'s ethnography for instance depicts gang members who have to exert violence to prove their masculinity. Costanza and Helms (2012)'s statistical study of gang activity and aggregate homicides demonstrated a correlation between the two. Gang violence is at the forefront of Huff (1996)'s edited volume. Even when violence is not central to the argument, we often know little about gang members' involvement in the informal economy (for instance Smith 2006:212-213). An important literature grew in reaction to these perspectives and took a keen interest in the informal economic activities of gangs - especially the drug trade.

During the crack epidemics, ethnographers found that gangs were displaying a new entrepreneurial spirit (Sanchez-Jankowski 1991; Padilla 1992; Venkatesh 1997; Venkatesh and Levitt 2000), leading gang members to make more rational, businessminded decisions. Venkatesh (1997) described the "corporatization" of the gang, and Padilla (1992) and Venkatesh and Levitt (2000) wrote about the emergence of the franchise model of drug selling among gangs. Ethnographers showed that this economic organization provided fewer opportunities for women and deteriorated sex work conditions (Maher and Daly 1996); and resulted in the gross exploitation of street-level operative (Padilla 1992; Fagan 1996)—especially ex-convicts unable to find legitimate employment (Scott 2004)-including the routine use of violence to enforce contracts, in the absence of a third-party to regulate business disputes (Venkatesh and Levitt 2000). Some have argued that the rise of the drug trade and the entrepreneurial shift among gangs occurred in light of the deindustrialization of the United States and the lack of opportunities for young black males in the formal economy (Fagan 1997, Coughlin and Venkatesh 2003). Young, urban black males saw drugs as a main source of income and status (Anderson 1990); gangs with more adult members were more likely to be criminal. The "institutionalization of drug markets" and the "second economies" that derived from it have had a "redistributive function" (Fagan 1996:62-65). In this conception, informal economies reward specific types of skills, creativity and agency.

\section{Conclusion}

This paper has outlined some of the key theoretical and analytic trends in the 
study of inequality and underground economies. To conclude our essay, we turn to some of the implications for future research by addressing methodological issues and research design challenges. We do so because systematic social science research on inequality presupposes an institutionalized recording of activity. In the United States, some common forms of documentation that inform our understanding of inequality include assessments of labor force participation by the Bureau of Labor Statistics, shifts in public welfare expenditures by the Department of Health and Human Services, and local trends in health care utilization by each State's public health division.

None of these established data streams exist for underground economic activities. Indeed, much of the informal economy by definition elides the very institutions that are responsible for producing such assessments. For this reason, we should not be surprised that substantive discussions of informal economic activity can be dominated by concerns over definition, generalizability, and, validity and reliability of data (Kanbur 2009). Alice Sindzingre (2006:60) describes the contemporary situation well by addressing the challenges that researchers face:

"Definitional problems also stem from the plurality of methodologies aimed at quantifying informal activities. There is no unique statistical aggregate that corresponds to the concept of informal economy. Statistical certainty is limited to the sub-sectors, such as the types of enterprises or employment that fulfill certain criteria of size, organization, payment of particular taxes, and so on."

As Sindzingre notes, with respect to informal economies, there is no accepted dataset, either within a single national context or globally, that might enable multiple researchers to offer competing explanations and shape theoretical propositions with a robust analytic exchange. For this reason, treatments of informal economic activity appear in several guises, though are limited in terms of producing representative findings. Perhaps the most common approach is to draw on qualitative research based on successful access to a set of individuals who are actively involved in hidden economic exchange. The advantages of this kind of methodological posture are several: extended interviews and/or observation can enable researchers to understand the shifting ways poor households draw on underground economies to make ends meet (Edin and Lein 1997); qualitative research can also highlight the complex interplay between illegitimate and legitimate economic circuits (Venkatesh 2013); and, single case studies typically demonstrate the significance of informal economic activity for the poor beyond their $d e$ jure criminal dimension (Duneier 1999). Qualitative research presents some notable challenges, however: to begin, it is not always easy to link together qualitative studies; an ethnographic study of textile workers in India and in the United States may employ differing definitions of informality - one finding that criminal operations must be included; the other finding them irrelevant-and so comparison become problematic (Patel 1990, see also NCEUS 2008); even if the group (say, a "gang") and the definition are similar, the research may have occurred in such widely different geographic circumstances (say, post-Communist Ukraine and modern-day Britain) that it becomes difficult to draw generalizations.

A second common research design appears in the work of contemporary economists. To adjust to the difficulties of comparing case studies that were conducted in different times and places, economists will use complex estimation procedures to draw inferences from existing datasets that document other aspects of the economy 
(Torgler and Schneider 2007, Elgin and Oztunali 2012). A common method is to make creative use of data on national GDP or tax reports. Torgler and Schneider's study (2007) demonstrates both the strengths and limitations of this perspective. Schneider and his colleagues draw on financial reporting from different countries to construct a multi-national informal economic dataset that enables basic comparison across countries of many different political and economic histories. These studies can alert officials about tax revenue loss or the large-scale social exclusion of a particular segment of society. They can be valuable for shaping social policies, such as labor protections or progressive tax-distribution, which might ameliorate inequality (c.f. Portes 1994). They can also enable local officials to spur economic growth by helping isolate those individuals who may need documentation, licensing, insurance, credit and other kinds of immediate economic catalysts (Amin 1994). However, like most others who use estimation methods, Schneider's construct does not incorporate any criminalized economies or even an estimate of household production. In other words it is limited to the behavior of organized firms. This is a common attribute of estimation models and there can be significant consequences for any attempt to draw conclusions about social inequality. Most importantly, the activities of low-income populations may never make it into the official financial reporting of firms, but are quite actively represented in informal domestic production and distribution, as well as in crime.

Finally, a third means of assessing informal economies is to launch large-scale surveys of a particular population of interest, such as small businesses of individual entrepreneurs (Chen et al. 2004, Crowell 2003). Macro surveys are extraordinary useful for understanding how informality shapes an entire economic industry. This sectoral based view can offer insight into the difficulties that low-income workers have in securing meaningful wages and stable employment. However, most attempts to give a broad overview face difficulty securing cooperation from their informants-whether individuals or firms - and so generalizability within and across a geographic region or commercial industry is compromised (Borotav, Yelden and Kose 2000; Narayana 2006). 


\section{References}

Aasved, Mikal. 2003. The sociology of gambling, Springfield, IL: Charles C. Thomas Publisher

Abu-Lughod, J. L. 1999. New York, Chicago, Los Angeles: America's Global Cities. U of Minnesota Press.

Alford, R.R. and Feige, E.L. 1989. "Information distortions in social systems: The underground economy and other observer-subject-policymaker feedbacks". In Feige (Ed.), The underground economy: Tax evasion and information distortion, pp. 57-81. Cambridge: Cambridge University Press

Amin, Ash. 1994 "The difficult transition from informal economy to Marshallian industrial district." Area: 13-24.

Anderson Elijah. 1999. Code of the Street: Decency, Violence, and the Moral Life of the Inner City. New York: W.W. Norton

Anderson, Elijah. 1990, Streetwise. Race, Class and Change in an Urban Community, Chicago: University of Chicago Press

Bangasser, P. E. 2000. The ILO and the informal sector: an institutional history. Geneva,, Switzerland: International Labour Organization.

Bernstein, Elizabeth. 2012. "Carceral politics as gender justice? The "traffic in women" and neoliberal circuits of crime, sex, and rights", Theory and Society, 41 (3), pp. 233-259

Boratav, Korkut, Erinç Yeldan, and Ahmet Köse. "Globalization, distribution and social policy: Turkey, 1980-1998." CEPA and The New School for Social Research, Working Paper Series 20 (2000): 113-114.

Bourgois, Philippe. 1996. In Search of Respect. Selling Crack in El Barrio. Cambridge, Cambridge University Press

Buchanan, J .M. 1990. Europe's constitutional future. London: Institute of Economic Affair

Castells, M., and Portes, A. 1989. "World underneath: The origins, dynamics, and effects of the informal economy". In Portes, A., Castells, M., and Benton, L. A. (Eds.). (1989). The informal economy: Studies in advanced and less developed countries. Baltimore: Johns Hopkins University Press.

Castells, Manuel, and Roberto Laserna. 1989 "The new dependency: Technological change and socioeconomic restructuring in Latin America." Sociological Forum, 4 (4), pp. 535-560.

Caulkins, J. and P. Reuter. 1998. “What Can We Learn from Drug Prices?” Journal of Drug Issues, 28 (3), pp. 593-612

Centeno, M. A., \& Portes, A. (2006). The informal economy in the shadow of the state. In Patricia Fernandez-Kelly and Jon Shefner (ed.), Out of the shadows: Political action and the informal economy in Latin America, Pennsylvania State University, pp. 23-48.

Chapkis, Wendy. 2000. "Power and Control in the Commercial Sex Trade," in R. Weitzer (ed.), Sex for Sale: Prostitution, Pornography, and the Sex Industry, New York: Routledge

Chen, M. A., Jhabvala, R., and Lund, F. 2002. Supporting workers in the informal economy: 
a policy framework. International Labor Organization.

Chen, M.A., J. Vanek and M. Carr (2004). Mainstreaming Informal Employment and Gender in Poverty Reduction: A Handbook for Policy-Makers and Other Stakeholders. Commonwealth Secretariat, London

Contreras, Randol. 2012. The Stickup Kids: Race, Drugs, Violence, and the American Dream. University of California Press

Cosgrave, James F. (ed.). 2006. The sociology of risk and gambling reader, New York: Routledge

Cosgrave, Jim and Thomas R. Klassen. 2001. "Gambling Against the State: The State and the Legitimation of Gambling", Current Sociology, 49 (5), pp. 1-15

Costanza, S. E. and Ronald Helms. 2012. "Street Gangs and Aggregate Homicides: An Analysis of Effects During the 1990s Violent Crime Peak", Homicide Studies, 16 (3), pp. 280-307

Coughlin, Brenda C. and Sudhir Alladi Venkatesh. 2003. "The Urban Street Gang after 1970", Annual Review of Sociology, 29: 41-64

Cross, T. L. 1969. Black capitalism: Strategy for business in the ghetto. New York: Atheneum.

Crowell, D.W. (2003). The SEWA Movement and Rural Development: The Banaskantha and Kutch Experience. Sage Publications, New Delhi.

Davis, Mike. 2006. Planet of Slums. London: Verso

De Soto, H. 1989. The Other Path. New York: Basic Books

De Soto, H. 2000. The Mystery of Capital, Basic Books

Decker, John. 1979. Prostitution: Regulation and Control, Littleton, Colorado: Rothman

Doeringer, P. B., and Piore, M. J. 1971. Internal labor markets and manpower analysis. ME Sharpe Inc.

Duneier, M. (1994). Slim's table: Race, respectability, and masculinity. University of Chicago Press.

Duneier, M. (1999). Sidewalk. Macmillan.

Eadington, W. R. 1976. Gambling and Society: Interdisciplinary Studies on the Subject of Gambling, Springfield, IL : Charles C. Thomas Publisher

Edin, K., \& Lein, L. (1997). Making ends meet: How single mothers survive welfare and low-wage work. Russell Sage Foundation.

Edin, K., and Lein, L. 1997. Making ends meet: How single mothers survive welfare and low-wage work. Russell Sage Foundation Publications.

Elgin, C., and Oztunali, O. 2012. "Shadow Economies around the World: Model Based Estimates". Bogazici University Department of Economics Working Papers, 5.

Elgin, Ceyhun, and Oguz Oztunali. "Shadow economies around the world: model based estimates." Bogazici University Department of Economics Working Papers 5 (2012).

Fagan, Jeffrey. 1996. "Gangs, Drugs and Neighborhood Change”, in Huff, C. Ronald (ed. ) 1996, Gangs in America. Second Edition, Thousand Oaks, CA: Sage, pp. 39-74

Farley M, Cotton A, Lynne J, Zumbeck S, Spiwak F, Reyes ME, Alvarez D, and Sezgin U. 2003. "Prostitution and trafficking in nine countries: Update on violence and posttraumatic stress disorder". Journal of Trauma Practice, 2(3/4):33-74

Feige, E.L. (Ed.). 1989. The underground economies: Tax evasion and information distortion. Cambridge: Cambridge University Press 
Ferman, L. A., Henry, S., and Hoyman, M. 1987. "Issues and prospects for the study of informal economies: Concepts, research strategies, and policy". The ANNALS of the American Academy of Political and Social Science, 493(1), 154-172.

Fitzpatrick, K. M. 1997. "Aggression and environmental risk among low-income African. American youth." Journal of Adolescent Health, 21, 172-178

Frey, James H. 1984. "Gambling: A Sociological Review", Annals of the American Academy of Political and Social Science, vol. 474, pp. 107-121

Fung, A. 2006. "Varieties of participation in complex governance". Public administration review, 66(1): 66-75.

Fusfeld, D. R., and Bates, T. M. 1984. The political economy of the urban ghetto. SIU Press.

Gaughan, J. P., and Ferman, L. A. 1987. "Toward an understanding of the informal economy". Annals of the American Academy of Political and Social Science, 15-25.

Gërxhani, K. 2004. "The informal sector in developed and less developed countries: A literature survey". Public choice, 120(3-4): 267-300.

Gilbert, A. 2002. "On the mystery of capital and the myths of Hernando de Soto: What difference does legal title make?". International Development Planning Review, 24(1): 1-19.

Grossman, G. 1977. "The 'Second Economy' of the USSR", Problems of Communism, 26(5), 25-40.

Hannerz, U. 1969. Soulside: Inquiries into ghetto culture and community. New York: Columbia University Press

Hart, K. 1973. "Informal income opportunities and urban employment in Ghana". Journal of Modern African Studies, 11(1): 61-89.

Hoigard, Cecilie, and Liv Finstad. 1992. Backstreets: Prostitution, Money, and Love, University Park: Pennsylvania State University Press, 1992

Huff, C. Ronald (ed. ) 1996. Gangs in America. Second Edition, Thousand Oaks, CA: Sage

International Labor Office. 1972. Employment, income and equality: A strategy for increasing productivity in Kenya. Geneva: ILO.

Jackall, R. 2009. Street stories: The world of police detectives. Harvard University Press.

Jencks, C., and Peterson, P. E. (Eds.). 1991. The urban underclass. Brookings Institution Press.

Kanbur, R. (2009). Conceptualising informality: regulation and enforcement (No. 4186). IZA discussion papers.

Katsenelinboigen A. 1990. The Soviet Union: Empire, Nation, and System. New Brunswick: Transaction Publishers

Katsenelinboigen, A. 1977. "Coloured markets in the Soviet Union". Europe-Asia Studies, 29(1), 62-85.

Khoury, Wavel. 1995. "Cultural conflicts and problem behaviors of Latino adolescents in home and school environments." Journal of Community Psychology 23.

Lautier, Bruno. 1994. L'économie informelle dans le tiers monde [The informal economy in the Third World], Paris: La Découverte

Leeson, Peter T. 2007. "An-arrgh-chy: The Law and Economics of Pirate Organization", Journal of Political Economy, 115 (6), pp. 1049-1994

Lewicki, R. J., Weiss, S. E., \& Lewin, D. (1992). Models of conflict, negotiation and third party intervention: A review and synthesis. Journal of organizational behavior, 13(3), 209-252. 
Lichter, D. T., \& Brown, D. L. 2011. Rural America in an urban society: Changing spatial and social boundaries. Annual Review of Sociology, 37, 565-592.

Light, Ivan. 1977. "Numbers Gambling Among Blacks: A Financial Institution", American Sociological Review, 42 (6), pp. 892-904

Losby, J. L., Else, J. F., Kingslow, M. E., Edgcomb, E. L., Malm, E. T., and Kao, V. 2002. Informal economy literature review. Newark: Institute for Social and Economic Development (ISED) and Washington: The Aspen Institute

Macleod J, Farley M, Anderson L, Golding J. 2008. Challenging men's demand for prostitution in Scotland. Glasgow: Women's Support Project

Maher, Lisa and Kathleen Daly. 1996. "Women in the street-level drug economy: continuity or change?", Criminology, 34 (4), pp. 465-491.

Marable, Manning. How Capitalism Underdeveloped Black America. New York: Pluto. 1983.

Marcelli, E. A., Pastor Jr, M., and Joassart, P. M. 1999. "Estimating the effects of informal economic activity: Evidence from Los Angeles County". Journal of Economic Issues, 579-607.

McRoberts, Omar M. 2005 Streets of glory: Church and community in a black urban neighborhood. University of Chicago Press.

Meares, T. (2002). Praying for community policing. California Law Review, 15931634.

Meares, T. 2008. "Legitimacy of Police Among Young African-American Men." Marquette Law Review 92: 651.

Meares, T. L., and Kahan, D. M. 1998. "Law and (norms of) order in the inner city". Law and Society Review, 805-838.

Merry, Sally Engle 1990 Getting Justice and Getting Even: Legal Consciousness Among Working-Class Americans. Chicago, I. University of Chicago Press.

Miller William J. and Martin D. Schwartz. 1998. "Casino Gambling and Street Crime", Annals of the American Academy of Political and Social Science, vol. 556, pp. 124137

Monto, Martin. 2000. “Why Men Seek out Prostitutes," in R. Weitzer (ed.), Sex for Sale: Prostitution, Pornography, and the Sex Industry, New York: Routledge

Moskos, P. 2008. Cop in the Hood. Princeton, NJ: Princeton University Press

Muncie, J. (2007). Youth justice and the governance of young people: Global, international, national, and local contexts. In Venkatesh, Sudhir Alladi, and Ronald Kassimir, eds. Youth, globalization, and the law. Stanford University Press, pp. 17-56.

Narayana, M.R. (2006), "Formal and Informal Enterprises: Concept, Definition, and Measurement Issues in India", in Basudeb Guha-Khasnobis, Ravi Kanbur and Elinor Ostrom (eds.) Linking the Formal and Informal Economy: Concepts and Policies, Oxford University Press, pp. 93-120.

National Commission for Enterprises in the Unorganised Sector (NCEUS) (2008), Report on Definitional and Statistical Issues Relating to Informal Economy, New Delhi.

Neal, Mark. 1998. "You Lucky Punters! A Study of Gambling in Betting Shops", Sociology, 32 (3), pp. 581-600

O'Connell Davidson, Julia. 1998, Power, Prostitution, and Freedom, Ann Arbor, Michigan: University of Michigan Press 
Padilla, Felix. 1992, The Gang as an American Enterprise, New Brunswick, NJ: Rutgers University Press

Patel, B.B. (1990), Workers of Closed Textile Mills: A Study in Ahmedabad, Gandhi Labour Institute, Ahmedabad.

Petry, Nancy M. 2005. Pathological gambling: Etiology, comorbidity, and treatment. Washington, D.C.: American Psychological Association

Portes, A., and Bach, R. L. 1980. "Immigrant earnings: Cuban and Mexican immigrants in the United States". International Migration Review, 14 (3), 315-341.

Portes, A., and Sassen-Koob, S. 1987. "Making it underground: Comparative material on the informal sector in western market economies". American Journal of Sociology, 93 (1), 30-61.

Portes, A., and Walton, J. 1981. Labor, class, and the international system. New York: Academic Press.

Portes, Alejandro.1994 "When more can be less: labor standards, development, and the informal economy." Contrapunto: The informal sector debate in Latin America: 113-129.

Quane, J. M., Rankin, B. H., and Joshi, P. 2009. “'It's Kind of Hard at Times': The Effects of Multiple Family Stressors and Welfare or Work Transitions on Low-income Adolescents". Working Paper 09-05, John Hopkins University.

Rauch, James E., and Peter B. Evans. 2000. "Bureaucratic structure and bureaucratic performance in less developed countries." Journal of public economics 75 (1): 49-71.

Reuter, P. 2003. “The Political Economy of Drug Smuggling” in Vellinga (ed.) The Political Economy of the Drug Industry Florida University Press. pp.128-147

Reuter, P. and J. Caulkins. 2004. "Illegal Lemons: Price Dispersion in the Cocaine and Heroin Markets" UN Bulletin on Narcotics, LVI (1-2), pp. 141-165

Rosen, Eva and Sudhir Alladi Venkatesh. 2008. "A "Perversion" of Choice. Sex Work Offers Just Enough in Chicago's Urban Ghetto", Journal of Contemporary Ethnography, 37 (4), pp. 417-441

Sampson, S. L. 1987. The second economy of the Soviet Union and Eastern Europe. The Annals of the American Academy of Political and Social Science, 493(1), 120-136.

Sanchez-Jankowski, Martin. 1991. Islands in the Street: Gangs and American Urban Society, Berkeley: University of California Press

Sassen, S. 1994. "Informal Economy: Between New Developments and Old Regulations", Yale Law Journal, 103 (8), 2289.

Sassen, S. 1999. Globalization and its discontents: Essays on the new mobility of people and money. New York: New Press

Sassen, S. 2001. The Global City: New York, London, Tokyo. Princeton University Press.

Sassen-Koob, S. 1984. "Notes on the incorporation of Third World women into wagelabor through immigration and off-shore production". International Migration Review, 1144-1167.

Schull, Natasha Dow. 2005. "Digital Gambling: The Coincidence of Desire and Design", Annals of the American Academy of Political and Social Science, vol. 597, pp. 6581

Scott Greg. 2004. “'It's a sucker's outfit'. How urban gangs enable and impede the reintegration of ex-convicts”, Ethnography, 5 (1), pp. 107-140 
Sindzingre, A. (2006). The relevance of the concepts of formality and informality: A theoretical appraisal. In Guha-Khasnobis, B., Kanbur, R., \& Ostrom, E. (2007). Linking the formal and informal economy: concepts and policies. Oxford University Press, pp. 58-74.

Skogan, W. G. 2004. Community policing: Can it work?. Thomson Wadsworth.

Skogan, W. G. 2006. Police and community in Chicago: A tale of three cities. Oxford University Press.

Smith, Robert Courtney. 2006. Mexican New York. Transnational Lives of New York Immigrants. Berkeley and Los Angeles, University of California Press

Stack, Carol B. 1974. All our kin: Strategies for survival in a black community. Basic Books.

Stark, D. 1989. "Bending the bars of the iron cage: bureaucratization and informalization in capitalism and socialism". Sociological Forum Vol. 4, No. 4, pp. 637-664

Surowiecki, J. 2013. "The Underground Economy", The New Yorker, April 29, retrieved on May $10^{\text {th }}, 2013$ at http://www.newyorker.com/talk/financial/2013/04/29/130429ta talk surow iecki

Thery, Clement. 2014. Larry's Clique: The Informal Side of the Housing Market in LowIncome Minority Neighborhoods, unpublished dissertation, Department of Sociology, Columbia University

Torgler, Benno and Schneider, Friedrich G. (2007) : Shadow economy, tax morale, governance and institutional quality: a panel analysis, CESifo working paper, No. 1923

Valentine, Betty Lou. 1978. Hustling and Other Hard Work. New York: The Free Press

Vega, W, and A Gil. 1999. "A model for explaining drug use behavior among Hispanic adolescents." Conducting Drug Abuse Research with Minority Populations: Advances and Issues:57-74.

Venkatesh, S. A. 1997. "The Social Organization of Street Gang Activity in an Urban Ghetto", American Journal of Sociology, 103 (1), pp. 82-111

Venkatesh, S. A. 2006. Off the books: The underground economy of the urban poor. Harvard University Press.

Venkatesh, S. A. 2008. Gang leader for a day: A rogue sociologist takes to the streets. Penguin

Venkatesh, S. A. and S. D. Levitt. 2000. "Are we a family or a business? History and disjuncture in the urban street gang", Theory and Society, vol. 29, pp. 427-462

Venkatesh, S.A. 2013. Floating City: A Rogue Sociologist Lost and Found in New York's Underground Economy. Penguin.

Venkatesh, Sudhir Alladi, and Ronald Kassimir, eds. 2007 Youth, globalization, and the law. Stanford University Press

Venkatesh, Sudhir. 2013. "Underground Markets as Fields in Transition: Sex Work in New York City." Sociological Forum, vol. 28, no. 4, pp. 682-699. 2013

Weitzer, Ronald. 2005. "New Directions in Research on Prostitution", Crime, Law and Social Change, vol. 43, pp. 211-235

Weitzer, Ronald. 2009. "Sociology of Sex Work," Annual Review of Sociology, vol. 35, pp. 213-234

Welte, John, Grace Barnes, William Wieczorek, Marie-Cecile Tidwell and John Parker. 2001. "Alcohol and gambling pathology among U. S. adults: Prevalence, 
demographic patterns and comorbidity", Journal of Studies on Alcohol, 62(5), pp. 706-712.

Williams, C., \& Windebank, J. 2001. Reconceptualising paid informal exchange: some lessons from English cities. Environment and Planning A, 33(1), 121-140.

Wilson, K. L., and Portes, A. 1980. "Immigrant enclaves: An analysis of the labor market experiences of Cubans in Miami". American Journal of Sociology, 86 (2): 295-319.

Wilson, W. J. 1987. The Truly Disadvantaged. The Inner City, the Underclass and Public Policy, Chicago: University of Chicago Press.

Wilson, WJ. 2009. More than just race: being black and poor in the inner city: WW Norton and Company.

Wood, Jane and Emma Alleyne. 2010. "Street gang theory and research: Where are we now and where do we go from here?", Aggression and Violent Behavior, vol. 15, pp. 100-111

Young, A. A. 2004. The minds of marginalized black men: Making sense of mobility, opportunity, and future life chances. Princeton University Press.

Zucman, G. 2013. "The Missing Wealth of Nations: Are Europe and the US net Debtors or net Creditors?". The Quarterly Journal of Economics. 128 (3): 1321-1364 